\title{
KONSEP EKOLOGI PADA RANCANGAN BALAI LATIHAN PENGOLAHAN SAMPAH DI BANJARBARU
}

\author{
Ahmad Al Hauri \\ Program Studi Teknik Arsitektur Fakultas Teknik Universitas Lambung Mangkurat \\ ahmadalhauri@gmail.com
}

\section{Dahliani}

Program Studi Teknik Arsitektur Fakultas Teknik Universitas Lambung Mangkurat dahliani.teknik@ulm.ac.id

\begin{abstract}
ABSTRAK
Berkembangnya kota Banjarbaru yang diiringi peningkatan jumlah penduduk dan aktivitas masyarakat berakibat pada meningkatnya jumlah buangan sampah yang dihasilkan. Pengolahan dan Pemilahan sampah yang idealnya perlu peran aktif masyarakat masih belum berjalan optimal, apabila kondisi tersebut dibiarkan, akan mengakibatkan jumlah sampah yang sebenarnya masih bisa diolah lebih banyak masuk ke Tempat pembuangan akhir (TPA) atau terbuang merusak lingkungan. Rancangan Balai latihan pengolahan sampah menggunakan konsep ekologis dengan penggunaan material daur ulang atau reuse material yang berasal dari sampah atau barang bekas. Konsep ekologis diterapkan dengan metode Interaktif yang mencakup elemen desain yaitu dinding, lantai, plafon, interior serta susunan massa dan lansekap. Konsep dan metode tersebut merupakan sebuah solusi untuk membuat rancangan yang dapat mengkomunikasikan pentingnya kepedulian masyarakat terhadap lingkungan dan pengolahan sampah.
\end{abstract}

Kata kunci: Balai Latihan, Pengolahan Sampah, Ekologi, Interaktif

\begin{abstract}
The development of the city of Banjarbaru accompanied by an increase in population and community activities resulting. An increase in the amount of garbage produced. The ideal waste processing and sorting needs and active role from the community is still not running optimally, if these conditions are left the amount of waste that can actually be processed more go more to a landfill or waste damaging the environment. The design of the waste management training center uses the ecological concept with the uses of recycled material or reuse material derived from waste or second thing. Ecological concepts are applied by interactive methods that include design elements namely the wall, floor, plafond, interior, and the composition of the mass and landscape. That concept and method is a solution to create a design that can communicate the importance of community care for the environment and waste process.
\end{abstract}

Keywords: Training Centre, Waste Processing, Ecology, Interactive 


\section{PENDAHULUAN}

Kota banjarbaru merupakan kota yang terus berkembang diiringi dengan peningkatan jumlah penduduk, aktivitas yang beragam serta pola konsumtif yang meningkat. Peningkatan pola tersebut berakibat pada jumlah buangan sampah setiap hari. Berdasarkan data dari Pengelola TPA gunung kupang banjarbaru tahun 2018, sampah yang masuk ke TPA mencapai 147 Ton perhari. Sampah tersebut dalam prosesnya masih ditimbun dan pemilahan oleh pemulung yang belum optimal. Apabila kondisi tersebut dibiarkan maka akan berujung pada penuhnya daya tampung. Perlu pengelolaan sampah yang ideal untuk mengurangi sampah yang masuk ke tpa dan dampaknya terhadap lingkungan.

Pemerintah Kota banjarbaru membuat pengalihan sebagian angkutan sampah ke Pusat Daur Ulang dan bank Sampah. Upaya tersebut berhasil mengurangi jumlah sampah yang masuk ke TPA menjadi 120 ton perhari (data bulan mei 2019 TPA). Namun hal tersebut belum mengurangi sampah dari sumber sampah. pengelolaan dan pemilahan sampah oleh masyarakat secara mandiri belum optimal sebagaimana yang diharapkan. Kondisi tersebut membuat pemerintah masih kesulitan mengurangi buangan sampah dari sumbernya. Idealnya masyarakat juga harus berperan aktif dalam pengurangan sampah. Peraturan Pemerintah RI Nomor 82 Tahun 2012 BAB 1 Pasal 1 Ayat 5 menyatakan bahwa produsen atau masyarakat juga harus berperan aktif dalam pengolahan sampah.

\section{PERMASALAHAN}

Pengolahan sampah oleh masyarakat memerlukan adanya pemberdayaan dan edukasi tentang pentingnya menjaga lingkungan melalui pengelolaan sampah. Belum adanya wadah yang menjadi fokus untuk kegiatan tersebut menjadi hal penting untuk perlunya dibuat sebagai upaya baru dalam mengatasi sampah dari sumbernya.
Konsep ekologis dipilih sebagai solusi desain berkaitan dengan edukasi dan pemberdayaan dalam masalah sampah terhadap lingkungan. Arsitektur Ekologis yang dipilih mencakup pemanfaatan material barang bekas dan potensi alam. Konsep perancangan ini diharapkan dapat mewujudkan masyarakat yang ramah terhadap lingkungan dan terjadi hubungan timbal balik antara manusia dan lingkungannya.

Pendekatan arsitektur ekologis diterapkan dengan metode interaktif untuk menciptakan komunikasi antara penghuni dan bangunan dan penghuni terhadap elemen desain yang diharapkan dapat memberikan pemikiran baru bahwa pengelolaan sampah tidak semuanya kotor. Cara tersebut yang digunakan dalam memicu masyarakat tertarik aktif mengolah sampah.

Berdasarkan uraian diatas penjelasan diatas Balai latihan sampah yang dirancang bertujuan sebagai upaya pengurangan dan pengolahan sampah di Banjarbaru berbasis masyarakat melalui kegiatan dan bangunannya. Oleh karena itu ruang, bangunan serta kegiatan pemberdayaan atau edukasi pengolahan sampah harus bisa mengkomunikasikan pentingnya kepedulian masyarakat terhadap terhadap masalah pengolahan sampah. Sehingga dampak sampah terhadap lingkungan dapat dikurangi, dan kepedulian terhadap lingkungan meningkat.

\section{TINJAUAN PUSTAKA}

\section{A. Balai Latihan Pengolahan Sampah}

Balai Latihan Pengolahan Sampah di Banjarbaru merupakan wadah informasi, sosialisasi tentang pengolahan sampah. Kegiatan pengolahan dan pengelolaan sampah juga diterapkan melalui workshop yang dibagi berdasarkan jenis sampah diantaranya : workshop botol bekas, plastik, kaca, kaleng, kayu, ban bekas dan kompos. Hasil olahan akan dipajang serta dijual untuk 
menjadikan peserta bisa mengolah sampah secara mandiri dan kreatif. Masyarakat atau peserta dan pengunjung yang pernah belajar di balai latihan ini dapat menjual dan memasarkan barangnya melalui balai, selain penjualan secara mandiri. Sehingga motivasi masyarakat ikut ditingkatkan.

\section{B. Ekologi}

Arsitektur ekologi merupakan konsep arsitektur yang memperhatikan keseimbangan dan keberlangsungan antara lingkungan dan bangunan.

Menurut mulyani dan frick (2006) Dalam buku arsitektur ekologis ,Kawasan hijau dan Taman juga diperlukan berkaitan dengan masalah lingkungan yaitu polusi udara (debu dan asap), udara yang semakin panas, berkurangnya ruang terbuka hijau, dan kebutuhan oksigen setiap hari.

Menurut frick dan suskiyatno (1998) dalam pembangunan ekologis ada 3 tingkatan yang perlu diperhatikan, pertama perencanaan nya, kedua pembangunan terhadap lingkungan dan ketiga bahan bangunan dan material yang sehat

Berdasarkan penjelasan diatas maka patokan yang digunakan dalam merancang balai yang ekologis yaitu :

- Menciptakan kawasan penghijauan di antara kawasan pembangunan sebagai paru-paru hijau.

- Menggunakan ventilasi alam untuk menyejukkan udara dalam bangunan.

- Menghindari kelembaban tanah naik ke dalam konstruksi bangunan dan memajukan sistem bangunan kering.

- Memilih lapisan permukaan dinding dan langit-langit ruang yang mampu mengalirkan uap air.
- Material daur ulang dan low energy.

\section{Metode}

Pendekatan arsitektur interaktif adalah suatu pendekatan hubungan timbal balik antara faktor, kelompok dan sistem yang mempengaruhi proses desain arsitektur. Tujuan desain interaktif adalah untuk menciptakan semacam hubungan timbal balik yang seimbang terhadap tujuan yang ingin dicapai (Parsaee dkk, 2016). Dalam rancangan ini fokusnya adalah bagaimana mengkomunikasikan sampah atau material yang bisa digunakan kembali kepada subjek untuk menyisipkan sebuah pesan pentingnya kepedulian terhadap lingkungan.

Interaktif dapat diterapkan dengan melalui visual dan sentuhan yang diterapkan pada elemen arsitektur salah satunya dengan material untuk menciptakan suasana menarik. Elemen- elemen tersebut bisa di desain pada bangunan baik fasad atau dinding, ruang terbuka sebagai elemen lansekap, elemen ruang. Konsep interaktif juga dapat dirancang untuk menghubungkan antara manusia dan lingkungannya. Tujuan pendekatan interaktif dalam desain adalah meningkatkan respon dan dampaknya terhadap manusia serta lingkungan sekitar. 


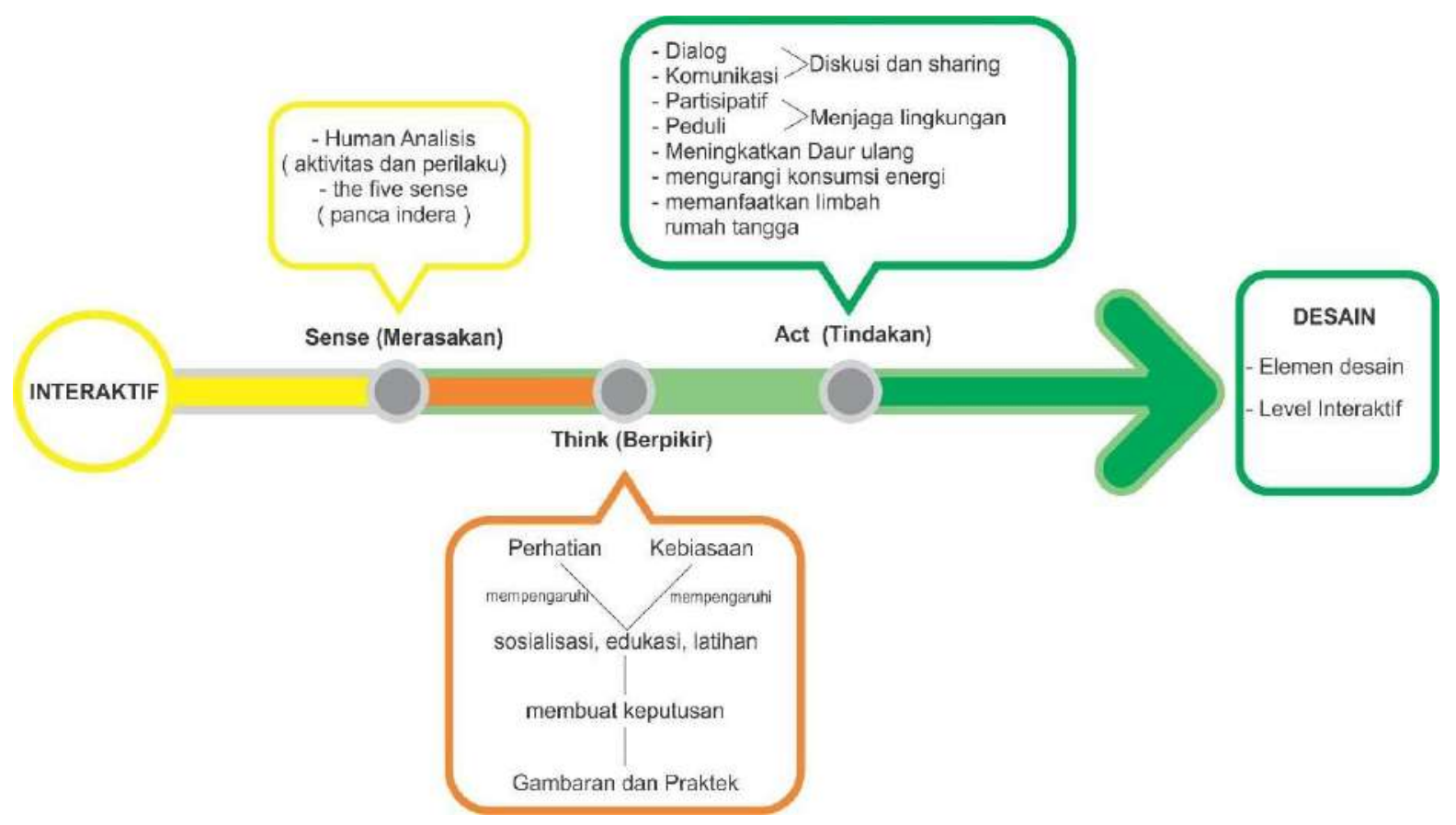

Gambar 1. Kesimpulan Tinjauan Interaktif

Sumber: Analisis Pribadi (2020)

\section{PEMBAHASAN}

\section{A. Fungsi Balai}

Fungsi pada balai latihan pengolahan sampah dibagi menjadi 3 fungsi berdasarkan tujuan utama pengajaran terhadap pengolahan sampah dan aktivitasnya yaitu :
1. Fungsi Utama
Wadah untuk memberikan edukasi bagaimana mengolah sampah secara mandiri.

2. Fungsi Penunjang

Sebagai tempat memproses sampah setelah masuk ke balai menjadi bahan baku pengolahan.

3. Fungsi Pendukung
Galeri, informasi dan kantin sebagai fasilitas komersial, taman untuk bersantai, istirahat, diskusi dan bercengkrama, Kantin sebagai tempat istirahat, kantor pengelola, area servis untuk mengelola balai dan asrama bagi pengunjung luar daerah.

\section{B. Lokasi Tapak}

Lokasi tapak yang dipilih berada di Jalan Trikora berdekatan dengan Pusat daur ulang (PDU) guntung paikat. Tapak merupakan lahan belum terbangun berdasarkan data persil lahan di Banjarbaru. 


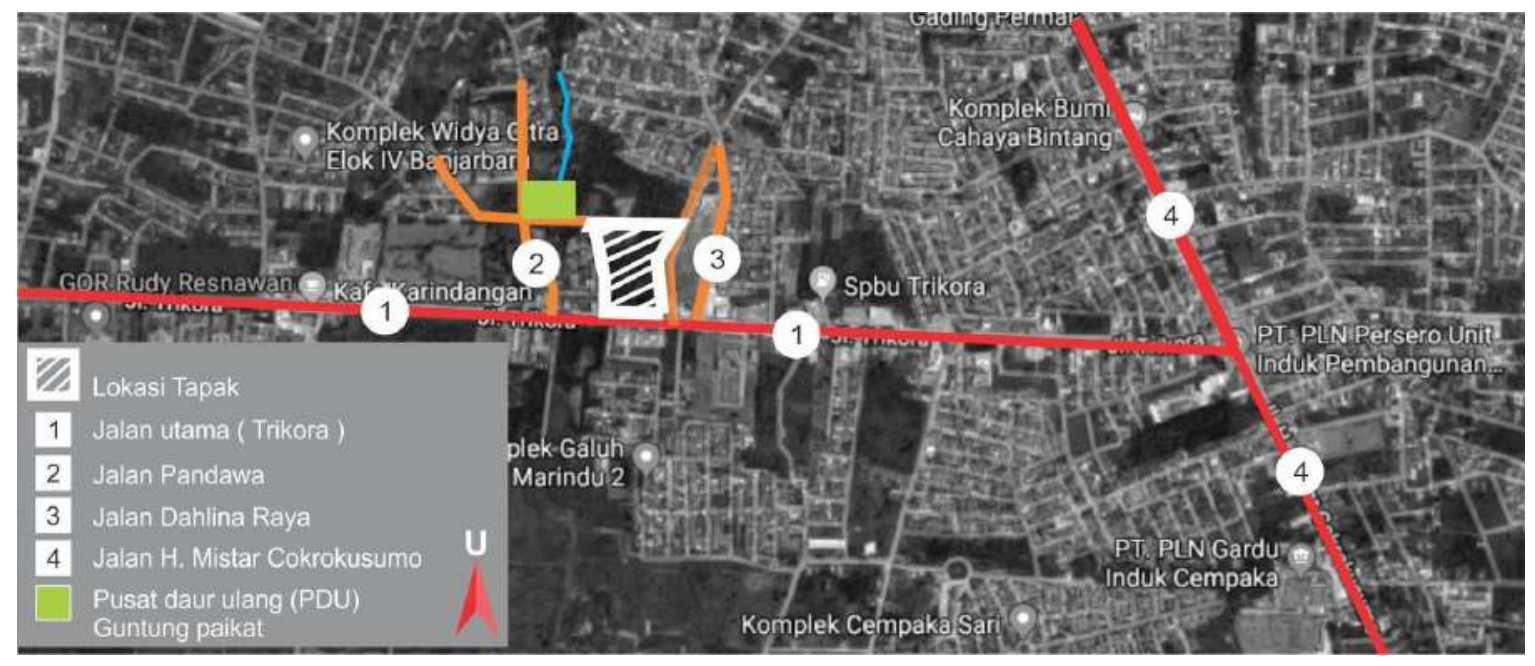

Gambar 2.Lokasi Tapak

Sumber: Analisis Pribadi (2020)

\section{Alur Pengolahan Sampah}

Sampah yang masuk dipilah terlebih dahulu sesuai jenis dan kode bahan, kemudian dikumpulkan sesuai jenisnya setelah itu sampah yang sudah terpilah dibersihkan dan dikeringkan dibawa ke gudang kemudian ruang pengolahan masing-masing.

1. Sampah Organik

Pengolahan sampah organik dilakukan dengan 2 cara, untuk skala besar dapat menggunakan mesin dan untuk pengolahan mandiri dapat menggunakan tong komposter.

2. Sampah Non Organik

Sampah non organik dikelola dengan 2 tahap pertama dibersihkan dan dikeringkan kemudian diolah menjadi kerajinan bernilai ekonomi.

\section{Aplikasi Metode Perancangan Interaktif dengan konsep ekologi}

Metode interaktif dengan menggunakan konsep arsitektur ekologis sebagai konsep perancangan diterapkan terhadap elemen desain arsitekturnya. komunikasi antara individu dan bangunan, individu antar individu dan bangunan, serta individu bangunan dan individu, terhadap elemen desain memiliki makna mendekatkan manusia dengan alam. material bekas juga digunakan sebagai makna bahwa sampah masih memiliki nilai dan bisa diolah secara mandiri.

Ekologi sebagai konsep perancangan utama diterapkan dengan menggunakan metode interaktif terhadap elemen desain untuk mengkomunikasikan tujuan dengan melalui alur interaktif yaitu pertama merasakan (Sense) terhadap indera manusia, kegiatan di dalam setiap massa dan material yang disusun dalam matriks (lihat gambar 4.2), dari perhatian terhadap alur merasakan (Sense) tersebut diharapkan dapat mempengaruhi proses berpikir terhadap perhatian dan kebiasaan melalui edukasi dan sosialisasi dalam mengelola sampah hingga sampai ke tahap tindakan (Action) yaitu sharing, diskusi dan berpartisipasi dalam mengelola sampah secara mandiri dan meningkatnya kepedulian terhadap lingkungan. 


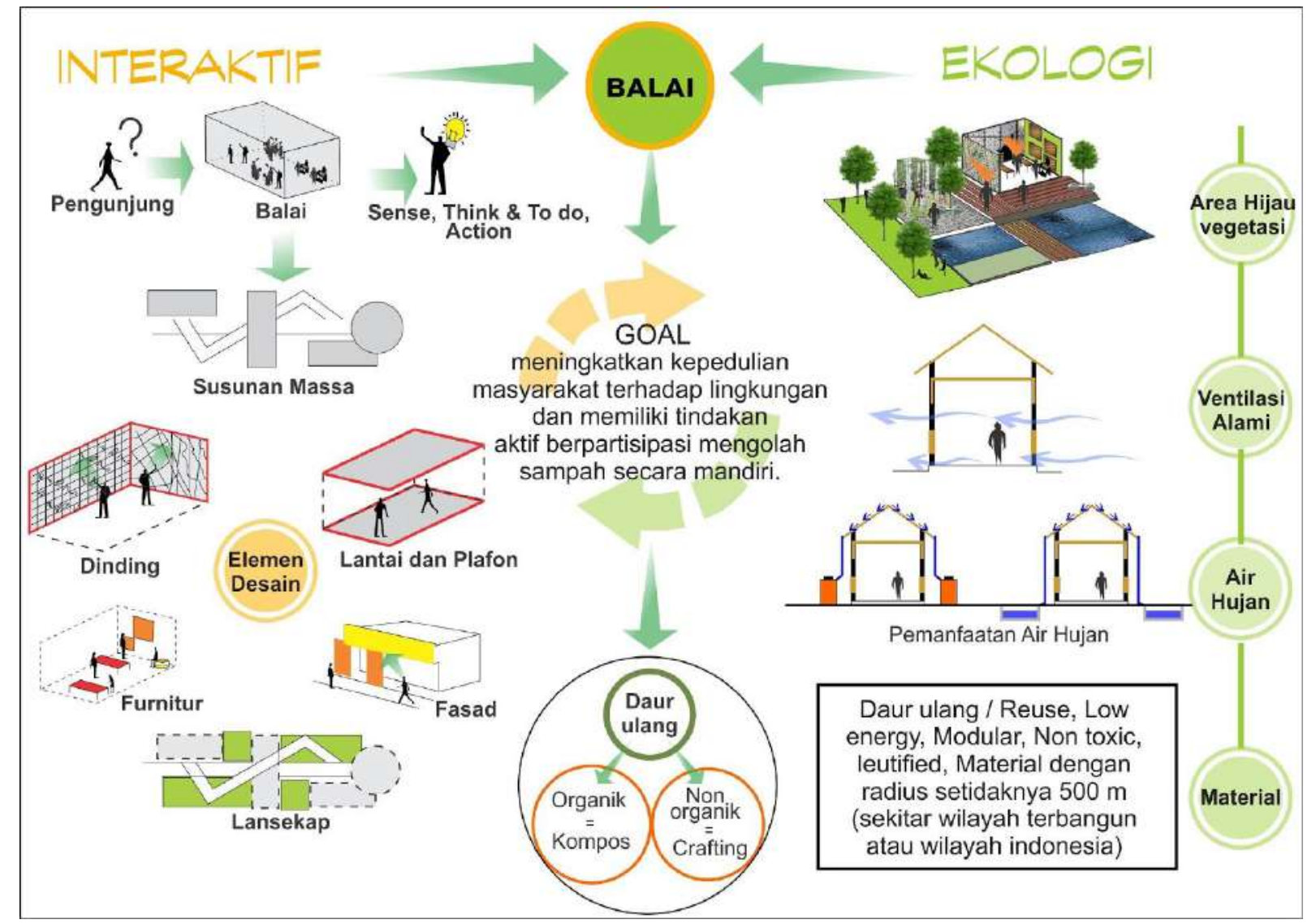

Gambar 3.Metode interaktif dan konsep ekologi terhadap balai

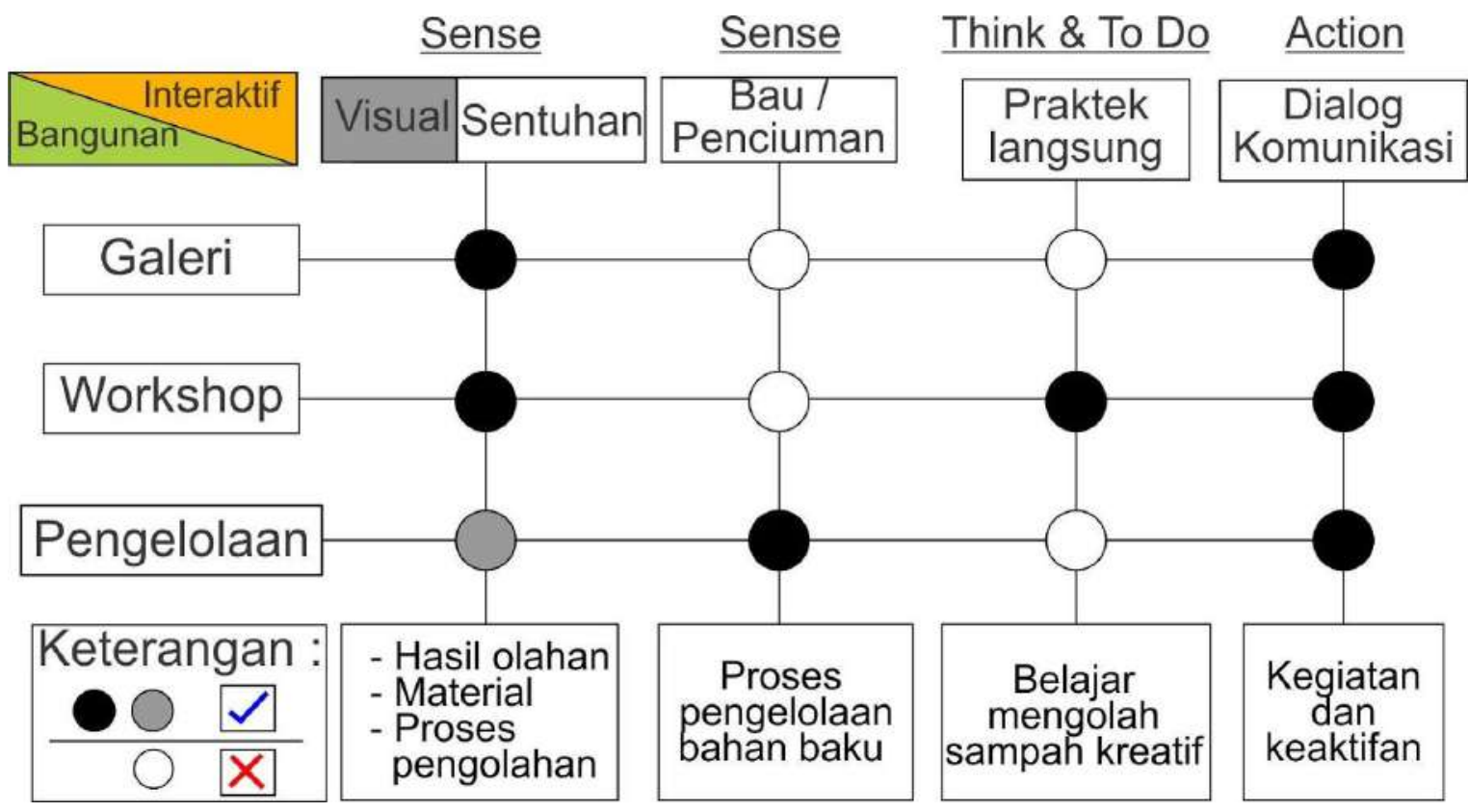

Gambar 4.Matriks interaktif 


\section{Organisasi Massa}

Susunan massa disusun sebagai acuan terhadap penataan ruang berdasarkan pertimbangan ( lihat gambar 4), Selain susunan massa hubungan antar massa juga disusun berdasarkan alur interaktif yang dirancang (Lihat gambar 5).

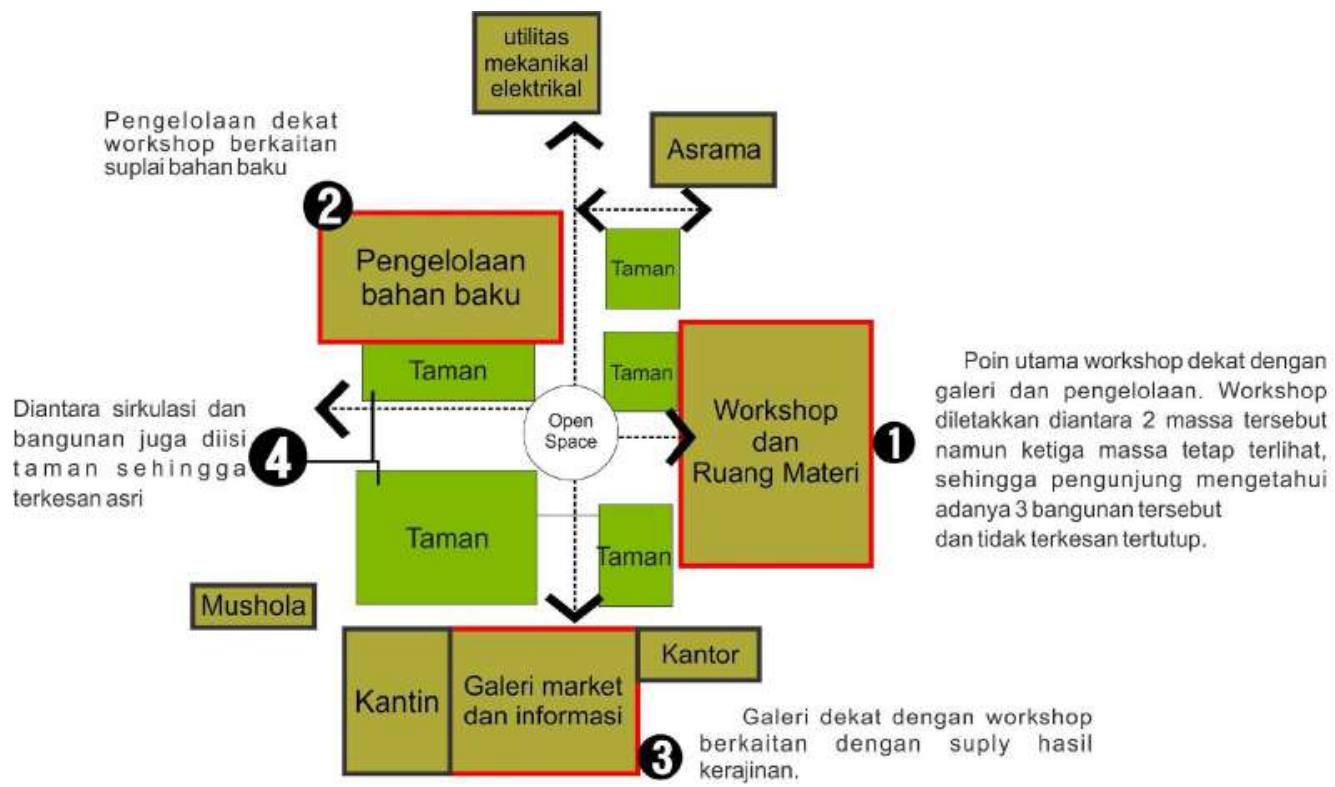

Gambar 5.Matriks interaktif

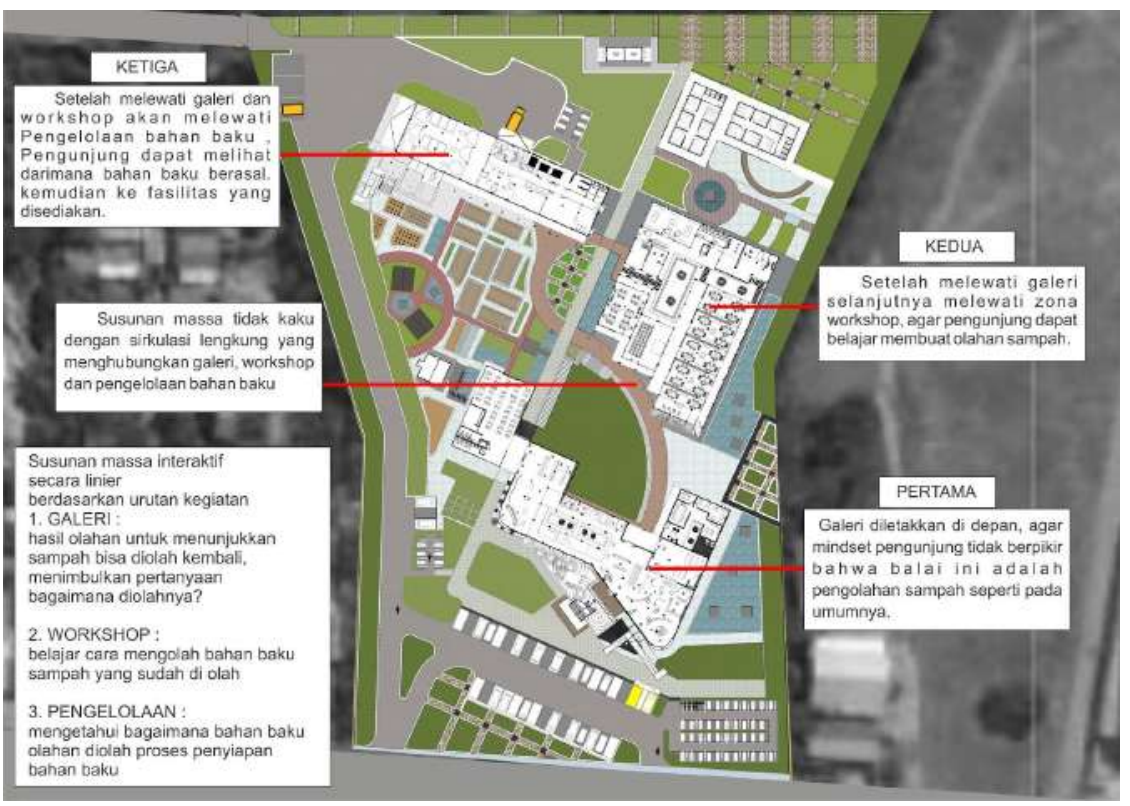

Gambar 6.Hubungan Massa 
2. Tampilan Bangunan

Karakter tampilan bangunan mengikuti konsep ekologi yang dikuatkan dengan material daur ulang kayu bekas, botol bekas dan botol kaca serta ecobrick Sehingga terlihat lebih komunikatif ( melalui visual melihat dan bisa disentuh) dan tidak kaku. Penggunaan material reuse atau daur ulang pada dinding atau fasade yang terlihat dari luar untuk mengkomunikasikan bahwa sampah atau barang bekas yang dibuang masih bisa dimanfaatkan.

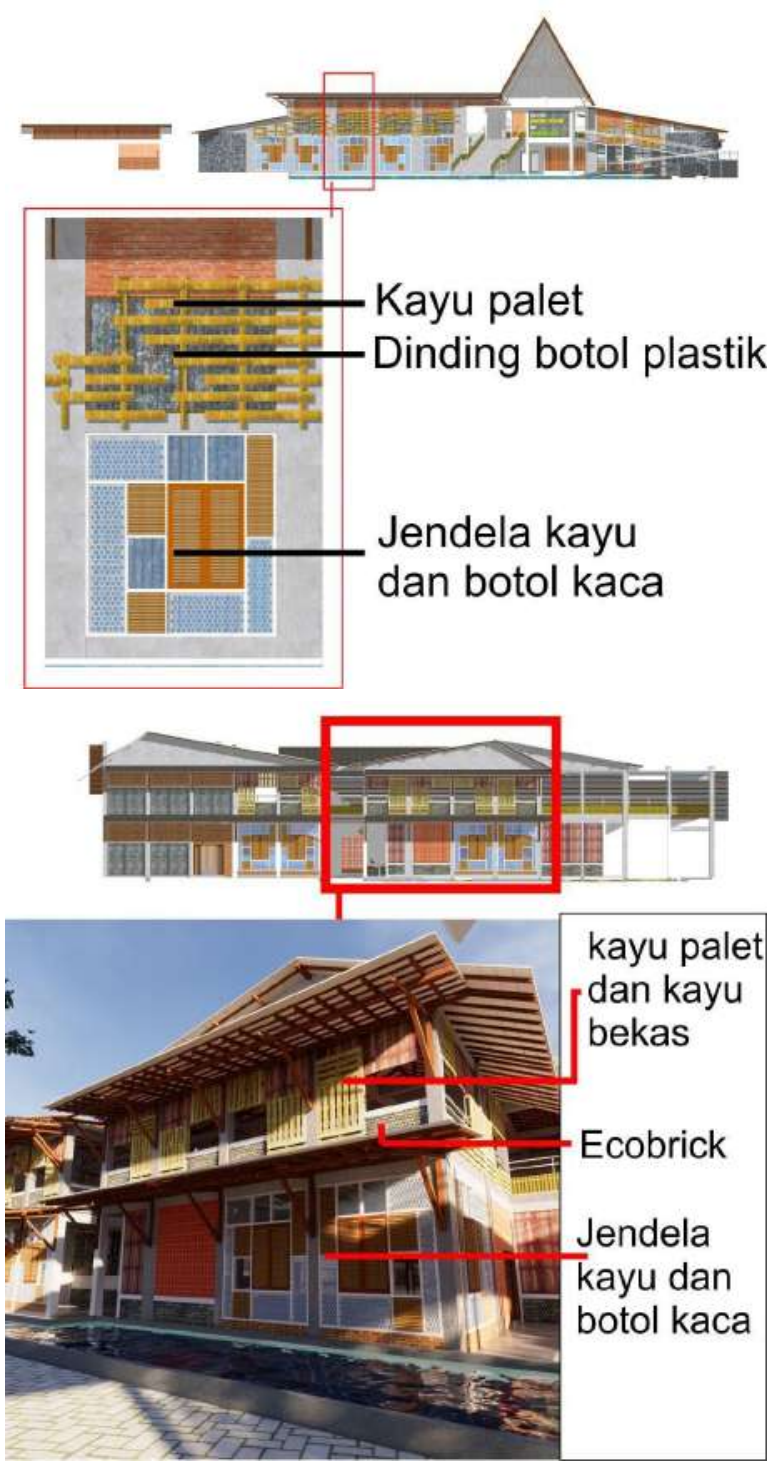

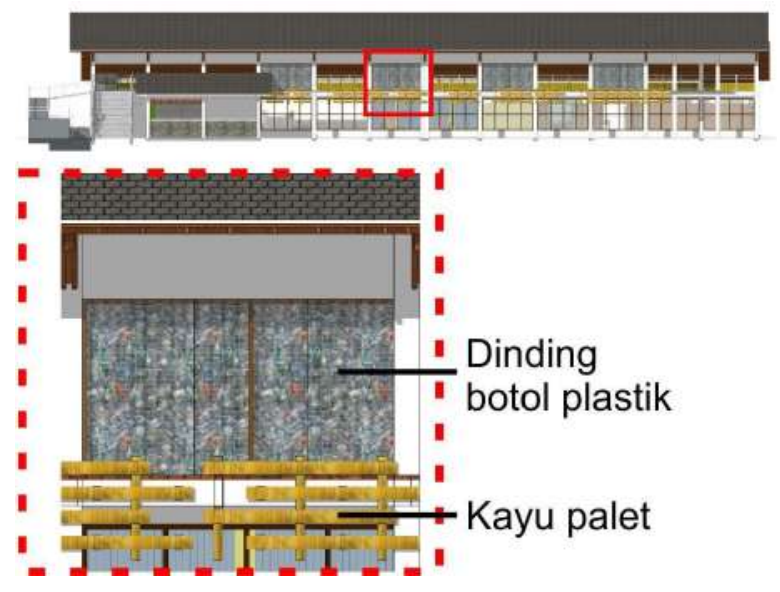

Gambar 7.Tampilan Bangunan Utama

3. Interior Bangunan

Interior bangunan menggunakan barang bekas seperti botol ecobrick botol kaca dan kayu bekas. barang bekas diterapkan pada elemen desain interaktif untuk interior : yaitu dinding, lantai, plafon, furniture. Dinding difungsikan sebagai partisi, material yang digunakan adalah botol bekas. Penggunaan botol sebagai pesan banyaknya sampah yang dibuang dan kemana sampah itu berakhir. Pada lantai menggunakan tutup botol bekas untuk interior bangunan galeri. Material plafon menggunakan kayu palet bekas dan botol bekas berisi sedikit air warna yang digantung. Furniture menggunakan barang bekas dari ban, kayu,botol dan kaleng, plastik. Kesan interaktif dan ekologis yang ditimbulkan adalah melalui visual dan sentuhan, dengan mengkomunikasikan bahwa sampah yang dibuang masih memiliki nilai lebih jika diolah dengan benar. 

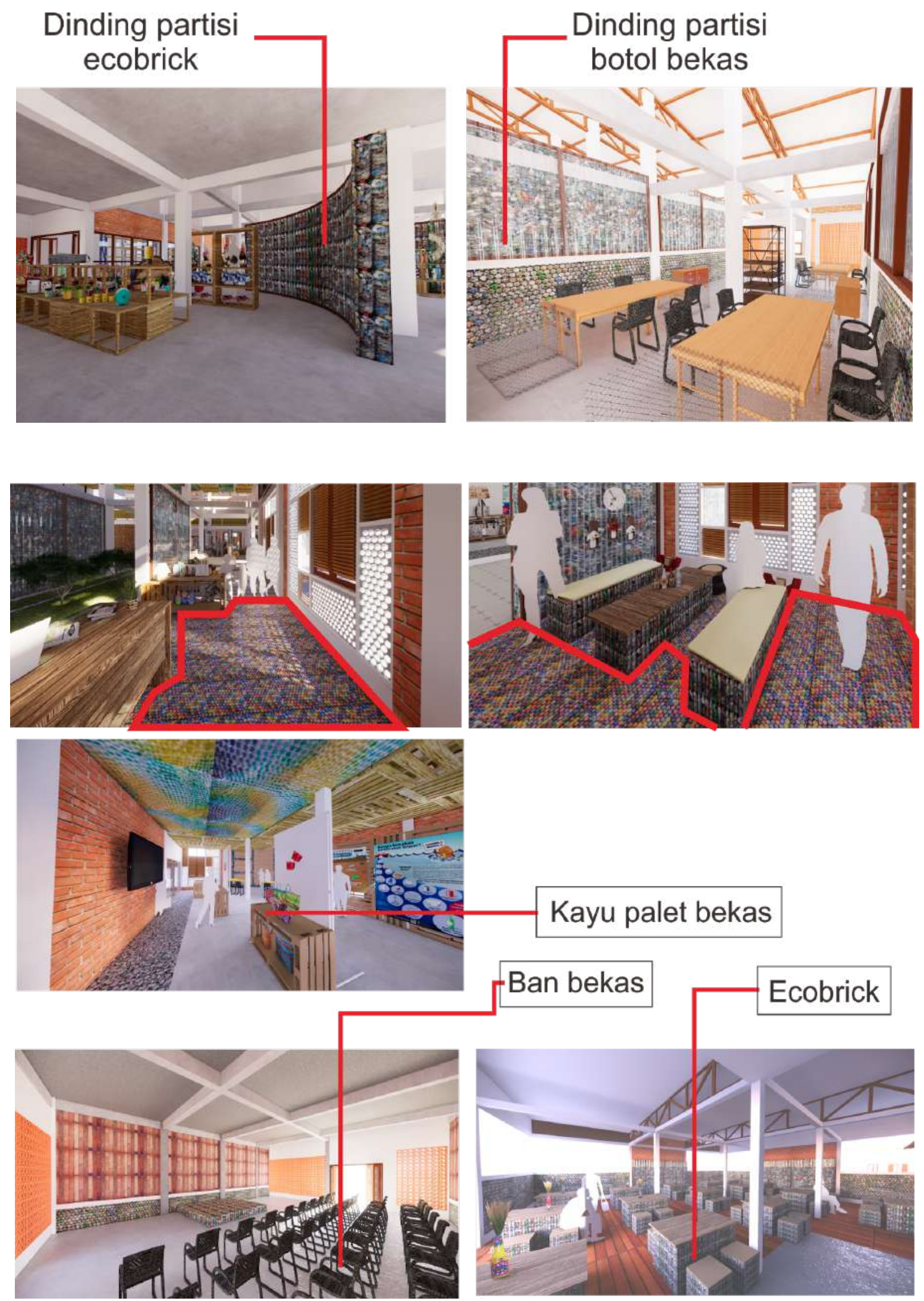

Gambar 8.Interior Bangunan 
4. Lansekap

Eksterior Ruang luar diberi elemen kolam dan pohon peneduh sehingga menghadirkan nuansa lingkungan asri. Material pada elemen lansekap menggunakan botol bekas seperti pada peneduh ( greenhouse terbuka) untuk kebun praktek kompos. Selain ruang luar di dalam bangunan juga di hadirkan taman sebagai penyejuk dan mendekatkan pengunjung dengan alam.
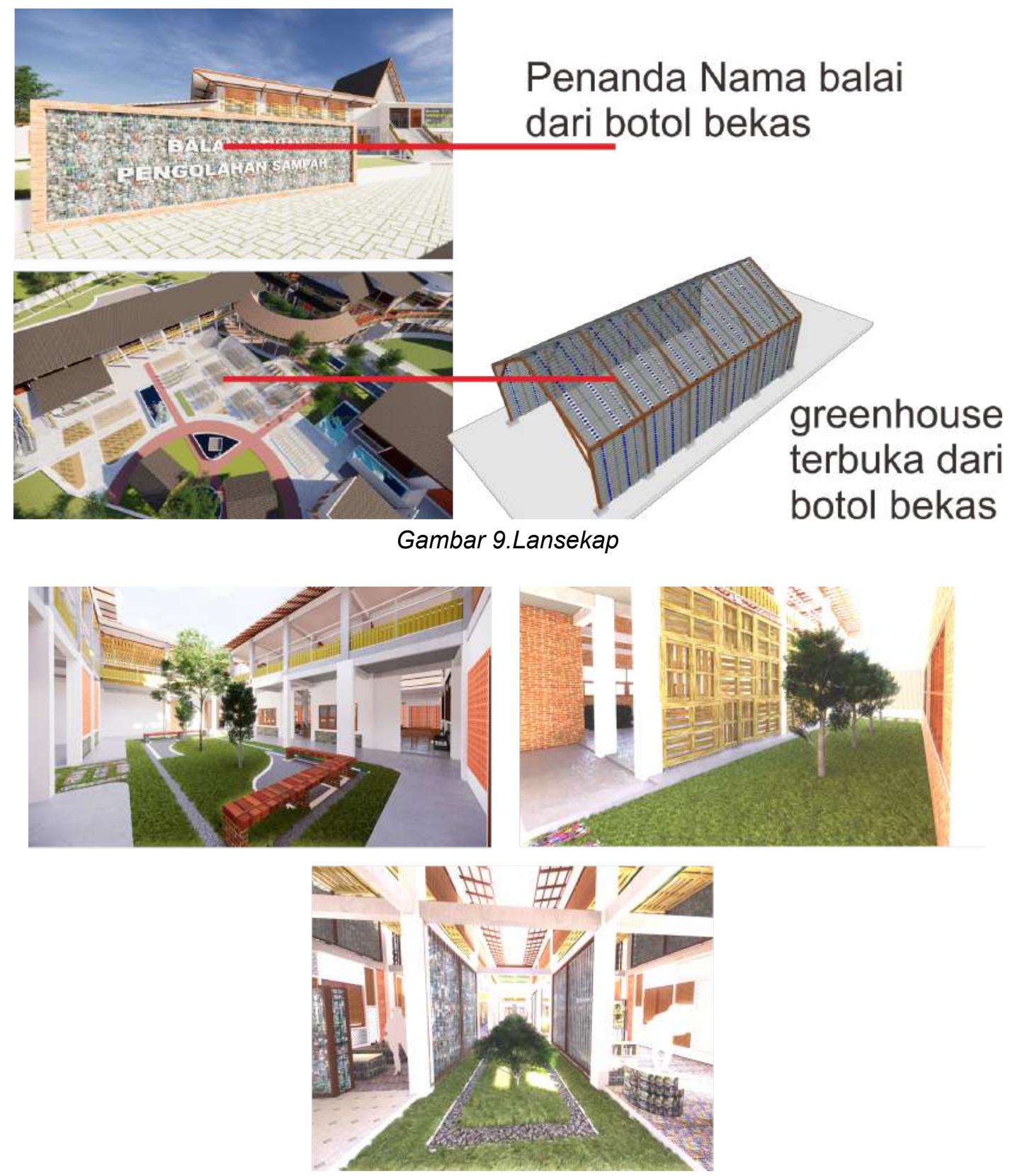

Gambar 10.Taman Dalam Bangunan 


\section{KESIMPULAN}

Balai Latihan Pengolahan Sampah di Banjarbaru sebagai tempat belajar dan edukasi masyarakat tentang pengelolaan sampah dan pengolahan sampah yang baik. Menggunakan konsep ekologis sebagai pendekatan terhadap lingkungan dan diterapkan dengan metode interaktif pada elemen desain dengan material yang ekologis (barang bekas). Untuk mengkomunikasikan pesan banyaknya sampah yang dihasilkan dan membuat masyarakat bisa mengolah sampah secara mandiri. Konsep dan metode diterapkan dengan cara :

1. Alur susunan massa yang membentuk alur kegiatan.

2. Matriks interaktif : melalui melihat, menyentuh, berpikir dan praktek, kemudian dialog. Terhadap material dan aktivitas yang dilakukan pada balai.

3. Material yang digunakan dari barang bekas untuk memancing ketertarikan pengunjung dalam belajar.

4. Sistem ekologis yang dipilih : adanya area hijau di luar dan dalam bangunan, ventilasi alami, pemanfaatan air hujan dan material bekas yang dimaknai untuk mendekatkan manusia dengan alam.

5. Lanskap atau taman di luar dan di dalam bangunan.

\section{DAFTAR PUSTAKA}

Achten henry.2019. Interaction Narratives for Responsive Architecture. Department of architectural modelling, Faculty of architecture, Czech Technical University in Prague,166 29 Prague, Czech Republic.

Data Laporan Timbangan TPA 2018 -mei 2019
Frick .H, FX Bambang Suskiyatno (1998), Dasar-dasar Arsitektur Ekologis, Penerbit kanisius, Yogyakarta.

Frick.H , Mulyani T.H. (2006), Arsitektur ekologis, Penerbit kanisius, Yogyakarta.

Frick.H ( 1996 ), Arsitektur dan lingkungan, Penerbit kanisius, Yogyakarta.

Parsaee M, Motealleh P, Parva M. 2016. Interactive architectural approach (interactive architecture): An effective and adaptive process for architectural design. Produksi Elsevier. Housing and Building National Research Center jurnal (2016) 12, 327-336

Peraturan Pemerintah Republik Indonesia nomor 81 tahun 2012 tentang Pengelolaan Sampah Rumah Tangga Dan Sampah Sejenis Sampah Rumah Tangga. 